\title{
整合性尺度を用いた構造的アラインメント
}

\author{
中澤 敏明
}

本論文では対訳文アラインメントの全体的な整合性を評価する新たな基準を提案す る.この手法は係り受けタイプによる木構造上での距離や, 距離スコア関数などの 統計的な素性に基づいている。 また依存構造木を元にしたアラインメント手法であ るため, 両言語間の言語構造の違いを適切に吸収することが可能である.さらに本 手法により，複数見つかる対応候補の中から適切なものを選択することも可能であ る。日英新聞記事コーパスでのアラインメント実験により, 本手法によるアライン メント精度は他の言語構造の近い言語対での精度と遜色ないことが示された。 キーワード: 機械翻訳, アラインメント, 木構造, 整合性, 係り受け距離

\section{Tree-based Phrase Alignment Based on Consistency Criteria}

\author{
TOSHIAKI NAKAZAWA ${ }^{\dagger}$ and SADaO KUROHASHI ${ }^{\dagger}$
}

In this paper, we propose a novel method to measure the consistency of alignment as a whole. It is based on probabilistic features, using dependency type distance and distance-score function. Since this method is based on tree structure, the linguistic difference between source and target language is successfully grasped. Moreover, with this method, appropriate correspondences can be selected among corresponding candidates. We conduct experiments on Japanese-English newspaper corpus, and achieve reasonably high accuracy compared with other language pairs which have less linguistic differences.

Key Words: Machine translation, Alignment, Tree structrue, Consistency, Dependency distance

\section{1 はじめに}

初期の機械翻訳の研究では, 翻訳のルールを人手により書き下して翻訳するルールベース翻 訳 (RBMT) が用いられていた. 計算機性能の問題もあり，しばらくはRBMTによる研究が進 められてきたが, 多様な言語現象を全て人手で書き下すことは事実上不可能であるし, 他の言 語対への汎用性がそしいなどの欠点がある. そこで次に考案されたのが，あらかじめ与えられ た対訳コーパスから翻訳知識を自動で学習し，その知識を用いて翻訳を行うコーパスベースの 手法である。

†京都大学大学院情報学研究科, Graduate School of Informatics, Kyoto University 
コーパスベースの手法で最も重要なのが, 翻訳で使う知識を対訳コーパスから学習するアラ インメントと呼ばれるステップである，アラインメント精度は翻訳精度を大きく左右するため, 現在までにアラインメントに関する研究が数多くなされてきた.

アラインメント研究の多くは, 対訳文を 1 次元の単語列として扱うものであり, その最も基本 的なモデルとして, 単語レベルでのアラインメントを統計的に行う IBM モデル (Brown, Pietra, Pietra, and Mercer 1993) が広く利用されている.IBM モデルでは原言語と目的言語の単語同士 の対応確率モデル (lexicon) や, 語順に関するモデル (distortion), 語数を合わせるためのモデル (fertility, null generation) などを統計的に学習する.

この単語列アラインメント手法を基礎として, アラインメント結果からより高度な翻訳知識 を学習する手法がいくつか提案されている. IBM モデルは 1 単語ごとでのアラインメントを行 うが, Koehn ら (Koehn, Och, and Marcu 2003) はIBM モデルによるアラインメント結果をべー スとして，そこから句に相当する部分を抽出する手法を考案し，翻訳の精度をより高めた。こ こでいう句とは，単語列を便宜上，句と呼んでいるだけであり，意味のまとまりを表している わけではなく，また句の階層的関係を扱うものでもない.

また Chiang (Chiang 2005) は単語列ではなく, 同期文脈自由文法に基づいた広い範囲の翻訳 パターンを学習する手法を提案した. Chiang の手法はKoehn らの手法による句対応結果から の学習を行うため，そのベースにはやはりIBM モデルがある.

このような発展的な翻訳知識学習の手法は, 翻訳においてある程度の文の構造を用いること につながるが，そのベースとなるアラインメント手法であるIBM モデルは，文の構造情報は一 切用いていない. このように単語列として文を扱う手法は, 英語とヨーロッパ言語など言語構 造に大きな違いがない言語対では精度よいアラインメント結果が得られるが，日英などのよう に言語構造が大きく異なる言語対に対しては不十分である。つまり言語構造が大きく異なる言 語対において高精度なアラインメントを実現するためには，アラインメントにおいても各言語 での文の構造を利用する必要がある。

アラインメントにおいて言語構造を扱う研究は, 古くは佐藤と長尾 (Sato and Nagao 1990) や Sadler と Vendelmans (Sadler and Vendelmans 1990), 松本ら (Matsumoto, Ishimoto, and Utsuro 1993)によって提案されたが, 当時は枠組を提案し, 短い文での実証を行ったのみで, 長い文, 複雑な文への適用実験などは行われなかった。しかしその枠組自体は現在でも十分有効なもの である。

また渡辺ら (Watanabe, Kurohashi, and Aramaki 2000)や Menezes と Richardson (Menezes and Richardson 2001) も構造を用いたアラインメント手法を提案している.これらの研究では, 比較的長く, 複雑な文のアラインメントを行っている. 文が長くなると, 対応関係の曖昧性が必 然的に増加し, これが問題となる。渡辺らは, 曖昧性のない語からの木構造上での距離を尺度 として曖昧性の解消を行い, Menezes と Richardson は確率的な辞書の情報を利用し, 最も確率 
の高い単語から順に対応付けることにより, 曖昧性解消を行ったが, いずれもヒューリスティッ クなルールに基づいた手法であり，木構造全体を整合的に対応付けることはしていない.

両言語の木構造を確率的に対応づける研究もある。このような手法は, 原言語文の木構造を 組み換えることにより，目的言語文の木構造を再現しようとするものであるが，構造を用いる ことの制約が強すぎるため，この制約をいかに緩めるかが議論の対象となる．Gildea (Gildea 2003) は原言語の任意の部分木を複製し, 目的言語の木構造を再現する手法を提案し, 韓国語と 英語を対象とした実験でアラインメントエラーレート (AER) (Och and Ney 2000) で 0.32 とい う高い精度を達成しており，言語構造を用いたアラインメントの有効性を示している。

しかし我々は，木構造に対してこのような操作を行う必要はなく，木構造をそのままアライ ンメントすれば良いと考えた，我々の手法は，佐藤と長尾などによって提案された手法を踏ま えつつ，ヒューリスティックなルールではなく，木構造全体を整合的に対応付けることを目的 とする。

本論文では，係り受け距離と距離一スコア関数を利用した，構造的木構造アラインメント手 法を提案する。本手法は依存構造木を利用しているため言語構造の違いを克服することができ， さらに木構造上の距離に基づいたアラインメント全体の整合性を，言語対に独立に測ることが できる，さらに構造情報を崩すことなく利用するため，豊富な翻訳知識の獲得も望める。

次章では我々の機械翻訳システムのアラインメントモジュールの基本的な部分について簡単 に紹介する．3章では我々が提案する手法を説明する．4 章では提案手法の有効性を示すために 行った実験の結果と結果の考察を述べ，最後に結論と今後の課題を述べる.

\section{2 構造的句アラインメント}

我々の機械翻訳システムは主に日英を対象としている，アラインメントは日本語，英語の構 文解析器や対訳辞書などを用いて，以下のステップにより達成される.

\section{1 依存構造解析}

日本語文は形態素解析器 JUMAN (Kurohashi, Nakamura, Matsumoto, and Nagao 1994) と構 文解析器 KNP (Kurohashi and Nagao 1994) を用いて依存構造木に変換される。依存構造木の 各ノードにはただ 1 つ内容語が含まれており，それに付随する助動詞や接尾辞などの機能語 は同じノードに含まれる。

英語文については，まず Charniak らの nlparser (Charniak and Johnson 2005) を用いて構文 解析し，さらにヘッドを定義するルールにより依存構造木に変換する．日本語の場合と同様， 各ノードは 1 つの内容語とそれに付随する機能語とからなる.

図 1 に木構造の例を示す。木構造のルートノードは一番左に配置されており，それぞれの句 


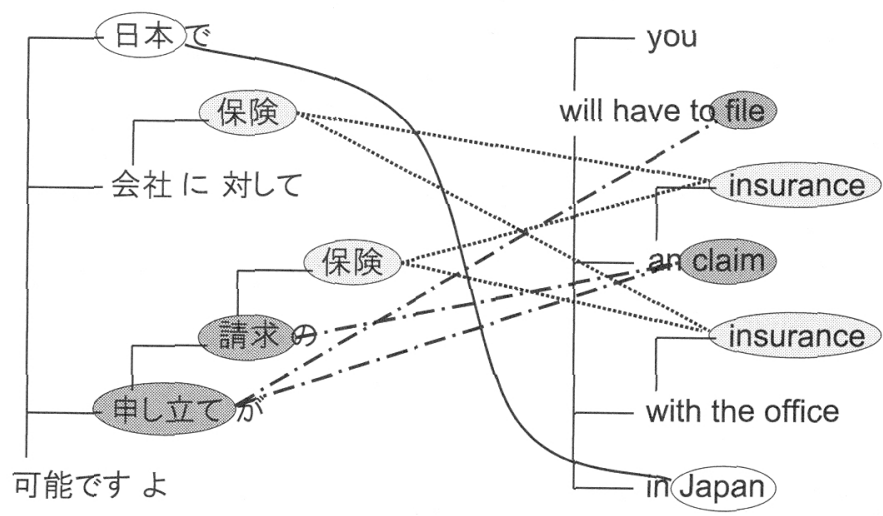

図 1 アラインメントの例

は上から下に語順どおりに配置されている。

\section{2 単語/句対応の探索}

日英間の単語/句対応の候補探索には, 対訳辞書, Transliteration, 数字のマッチング, 部分 文字列アラインメントなどいくつかの手がかりを利用する。

\subsection{1 対訳辞書}

日本語の単語と英語の単語の全ての組み合わせを対訳辞書から探し, 対応候補を見つける。 このとき，1語ずつではなく複合名詞などの複数語の探索も行う。また現時点では対訳辞書に は確率的な情報は含まれていない。

\subsubsection{Transliteration}

日本語で形態素解析器によって人名や地名などの固有名詞と判定された語や, 一般的に外来 語に用いられることの多いカタカナ語に対して, 英語への transliteration 候補を自動的に生成 し，これら候補と英語文に現れる単語との類似度を計算する。類似度は編集距離を元にして計 算され，類似度が閾值を越える組み合わせがあった場合，それらを対応候補とする。

例えば以下の例は対訳辞書では対応候補として得られないが，transliterationにより対応候補 とされる。

新宿 $\rightarrow$ Shinjuku $\leftrightarrow$ Shinjuku （類似度 : 1.0)

ローズワイン $\rightarrow$ rosuwain $\leftrightarrow$ rose wine (類似度：0.78） 


\subsection{3 数字のマッチング}

それぞれの言語において異なる数字表現を算用数字に汎化することにより，対応候補を得る. 例えば日本語の「二百六十万」と英語の “2.6 million” は共に同じ数字 “2600000”を表している ため，それぞれ汎化することにより対応候補とすることができる.

\subsection{4 部分文字列アラインメント}

対訳文の中には特別な言い回しや辞書に載っていない専門用語などを含んだもの，文の内容 に過不足があるものなどが存在する。これまで挙げた手がかりだけでは，このような対訳文を 正確にアラインメントするのに十分な対応候補を見つけることができない場合がある。このた め，言語資源に依存しない統計的なアラインメント手法も併用することが必要となる.

統計的手法として, 我々は Cromieres の手法 (Cromieres 2006) を利用した。この手法は, 対 訳コーパス中の各言語の任意の部分文字列（分かち書きされている場合は単語列）の共起頻度 を元にして対訳文のアラインメントを行う手法である。任意の部分文字列についてアラインメ ントするため形態素解析が不要な点, また Suffix Array を用いて高速にアラインメントできる 点で優れている.

例えば以下の対訳文を考える。

Source: 参院選での社会党の大敗は必至と言われる.

Target: It is said that the Social Democratic Party will suffer a major loss at the House of Councillors election.

対訳辞書情報から得られる対訳候補は“言われる↔ said that”のみであり，不十分だが， Cromieres の手法を用いることにより“参院↔ the House of Councillors”, “選 ↔ election”, “の 社会 ↔ the social”, “党の↔ Democratic Party”の各対応が得られる.

\section{3 適切な対応候補の選択}

前章で得られた対応候補の中には, 曖昧性を持つ候補や, 曖昧ではないが文脈上不適切な候 補が含まれることがある。

例えば図 1 において，日本語の “保険”と英語の “insurance”はそれぞれ 2 度ずつ出現してお り，組み合わせで 4 つの対応候補が得られることになり，曖昧性が生じるささらに“申し立て” の訳語として “file”と“claim”の 2 つがみつかり，ここでも曖昧性が生じる。このため，見つ かった対応候補の中から適切な候補のみを選び出す基準が必要となる。これについての詳細は 3 章で述べる。

\section{4 未対応ノードの処理}

ここまでの処理により対訳文間にいくつかの対応が見つかったが，いくつかのノードが対応 付けられずに残る場合がある。これらのノードは簡単なルールにより他の対応に併合する。 
まず日本語，英語ともに名詞句内で未対応部分があれば名詞句内の他の対応に併合し，それ 以外の未対応ノードはすべて親ノードの対応に併合する。ただし, 節の区切りなどの大きな区 切りを越えての併合は行わない.

\section{3 整合性尺度に基づく構造的句アラインメント}

対訳文全体として整合的なアラインメントを行うために，任意の 1 組の対応に対して整合性 スコアを定義する．最も整合的なアラインメントは整合性スコアの平均を最大とするような対 応候補の組み合わせとして得られる。

$$
\underset{\text { alignment }}{\operatorname{argmax}} \frac{\sum_{i=1}^{n} \sum_{j=i+1}^{n} \text { 整合性スコア }\left(a_{i}, a_{j}\right)}{n(n-1) / 2}
$$

上式で $a_{i}$ と $a_{j}$ は互いに異なる任意の対応候補であり, 整合性スコアは対応候補のペアに対し て定義される。整合性スコアの定義については次章以降で詳しく述べる。

\section{1 アラインメントの整合性}

アラインメントの精度を左右するのは, 曖昧な対応や誤った対応が含まれるたくさんの対応 候補の中から，いかに正しいものを選択するかである。これを実現するために，対訳文全体を 整合的に対応付けられるロバストな手法が必要である。

英語とヨーロッパ言語のように言語構造の似た言語対ならば，広く研究されている統計的な 手法でも高精度にアラインメントすることが可能であるが, 日本語と英語では言語構造が大き くことなるため, 統計的な手法での高精度なアラインメントは難しい. しかし我々の MT シス テムは依存構造木をベースとした深い言語処理を行っているため, リッチな情報を利用して言 語構造の違いを吸収できるようなアラインメントが可能である.

我々の提案する手法を説明する前に，アラインメントの整合性とは何かを考えてみよう. 図 2 において，それぞれの三角形は各言語の木構造上の節を表しており，2つの木構造にまたがっ て引かれた直線の 1 つ つが対応候補を表している。すべての対応候補のうちで，×印が記さ れた候補が全体の整合性を低下させていることが見て取れる.

このような不整合は視覚的には明らかである。この不整合さを定量的に評価するために, 我々 は一組の対応候補の木構造上での距離に注目する。図 2 の例で×印が記された候補と他の $1 つ$ の候補とに注目すると，原言語側での 2 つの直線の距離は遠いのに対して, 目的言語側では非 常に近い. 句の依存情報を元にした木構造上で議論すると，このようなことが起こることは稀 である。つまり，一方の言語で構造的に近い句同士が他方の言語では遠くなるようなことはほ ぼありえないということである。 


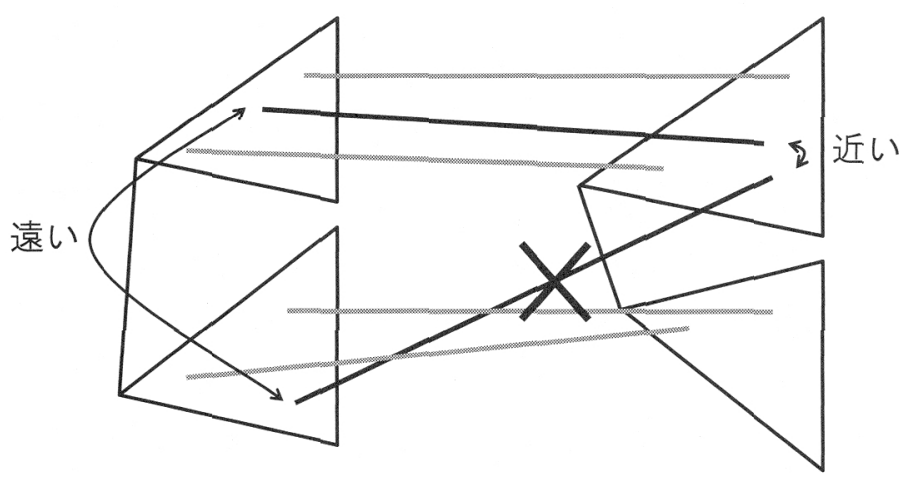

図 2 整合性の例

このように，あらゆる対応候補のペアの距離を適切に扱うことにより，全体的に整合的なア ラインメントを得ることができると考えられる。この距離を扱うために，我々は次章で説明す る整合性スコアを提案する。

\section{2 整合性スコア}

整合的なアラインメントを得るために，依存構造木上で整合性スコアを定義する。整合性久 コアは $2 つ 1$ 組の対応候補に対して計算され，対応候補ペアの距離の関係が適切ならばプラス， そうでなければマイナスのスコアとなる。

まず，任意の対応候補ペア $a_{i}\left(p_{S i}, p_{T i}\right)$ と $a_{j}\left(p_{S j}, p_{T j}\right)$ に注目する。 $p_{S i}$ と $p_{T i}$ はそれぞれ対 応候補 $a_{i}$ によって対応ら゙けられている原言語, 目的言語の句を表しており， $p_{S j}$ と $p_{T j}$ も同様 である。

原言語側の係り受け距離 $d_{S}\left(a_{i}, a_{j}\right)$ は, $p_{S i}$ と $p_{S j}$ の間の木構造上での距離として定義され, 目的言語側についても同様に $d_{T}\left(a_{i}, a_{j}\right)$ が定義される。この距離を用いて整合性スコアは以下 のように計算される。

$$
\text { 整合性スコア }\left(a_{i}, a_{j}\right)=f\left(d_{S}, d_{T}\right)
$$

ここで $d_{S}$ は $d_{S}\left(a_{i}, a_{j}\right)$ を省略して表記したもので， $d_{T}$ も同様である。 $f\left(d_{S}, d_{T}\right)$ は原言語側と 目的言語側の距離のペアをスコアに変換する関数であり，距離一スコア関数と呼ぶ。係り受け 距離と距離スコア関数については次章で詳しく述べる。

対訳文全体のアラインメントの整合性は, 式1に表されるように，あらゆる組み合わせの対 応候補ペアの整合性スコアの和として定義される。

正しい対応候補は，その近くにある対応候補により支持され，プラスのスコアが与えられ，さ らに全体のアラインメントの整合性に寄与する。ここで，近くにある対応候補とは，原言語側， 
目的言語側ともに，距離が小さい対応候補ということである.

\section{3 係り受け距離}

この章では，係り受け距離 $d_{S} や d_{T}$ の計算方法を説明する．最も単純な設定としては，すべ ての枝の距離を 1 とし, 係り受け距離はあるノードから別のノードまでに通る枝の数とするこ とが考えられる。しかしながら，高度な言語処理技術により得られる知識を利用し，より精度 の高いシステムの構築を目指すことは自然である.

日本語依存構造解析器 KNP および英語の Charniak の nlparser はそれぞれ係り受けタイプの 情報を出力する。これらの情報を利用して，係り受けタイプスコアを定義する。このスコアは 係り受けの強さ，つまり枝の距離を表しており，係り受けの強さが強い（区切りが弱い）ほど 小さく，係り受けの強さが弱い（区切りが強い）ほど大きくなるように設定する. 例えば複号 名詞内の形態素の区切りなどは係り受けが強いのでスコアは小さく, 逆に節の区切りなどは係 り受けが弱いのでスコアは大きくなる.

係り受けタイプは高々 30 種類程度しかないため, 係り受けタイプスコアは人手により設定す る. 図 3 にその一部を示す。日本語の係り受けタイプは南による分類 (南 1993) に基づいて, 構 文解析器 KNP (Kurohashi and Nagao 1994) が出力するものである.スコアの值は主観的に定 義したものであり，正確に言語現象を反映した值ではない可能性がある。この值を自動学習に より設定することは，今後の課題である.

係り受けタイプスコアを実際の対訳文に適用した例を図 4 に示す。図 4 で各枝上のラベルが 係り受けタイプを示しており，その上の数字が係り受けタイプスコアである.

係り受け距離 $d_{S}$ や $d_{T}$ は, あるノードから別のノードまで最短ルートでたどるときに通る枝 の係り受けタイプスコアの和と定義する。例えば図 4 でペア 1 の距離は, 日本語側 $\left(d_{S}\right)$ は“保 険 $\rightarrow$ 請求 の” の枝を通るので, $d_{S}=1$ となり，英語側 $\left(d_{T}\right)$ は “insurance $\rightarrow$ an claim” の枝を 通るので， $d_{T}=1$ となるため， $\left(d_{S}, d_{T}\right)=(1,1)$ となる（図で丸で囲まれた数字のある枝を通 る). 同様にペア 2 の距離は，日本語側はペア 1 と同じで $d_{S}=1$ だが，英語側は “insurance $\rightarrow$

\begin{tabular}{|l|l|}
\hline \multicolumn{2}{|c|}{ 日本語 } \\
\hline 連用:レベル C & 6 \\
\hline 連用:レベル B +/B & 5 \\
\hline 連用:レベル B - /A & 4 \\
\hline ノ格/連体 & 2 \\
\hline $\begin{array}{l}\text { 文節内 } \\
\text { 連用:レベル A - }\end{array}$ & 1 \\
\hline その他 & 3 \\
\hline
\end{tabular}

\begin{tabular}{|l|c|}
\hline \multicolumn{2}{|c|}{ 英語 } \\
\hline S/SBAR/SQ ... & 5 \\
\hline VP/WHADVP & 4 \\
WHADJP & \\
\hline ADVP/ADJP & 3 \\
NP/PP/INTJ & \\
QP/PRT/PRN & \\
\hline その他 & 1 \\
\hline
\end{tabular}

図 3 係り受け距離の定義の例 


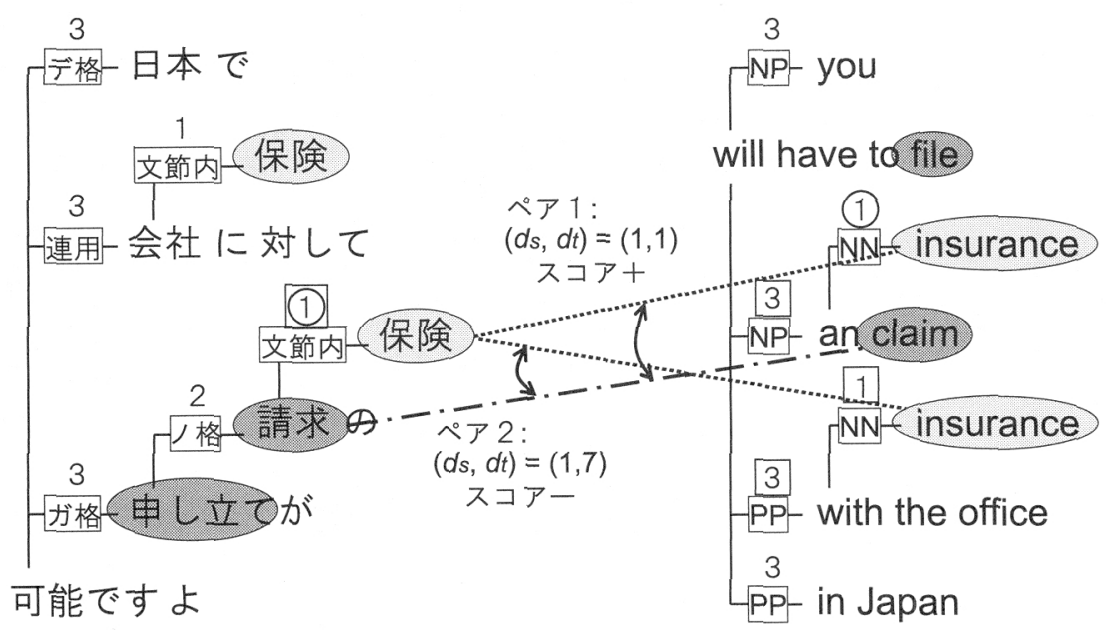

図 4 倸り受け距離とスコアの例

with the office", "with the office $\rightarrow$ will have to file", "an claim $\rightarrow$ will have to file" の $3 つ の$ 枝を通るので，枝の距離を合計して $d_{T}=7$ となるため， $\left(d_{S}, d_{T}\right)=(1,7)$ となる（図で四角で 囲まれた数字のある枝を通る)。

木構造を用いずに単純な単語列として見た場合，2つの “insurance”はどちらも"claim”から 近いと判断されてしまうため，正しい曖昧性解消ができなくなる。このようなことは他の例で もしばしば起こりうることであり，木構造を用いることの利点がここで示される。

\section{4 距離一スコア関数}

距離スコア関数 $f\left(d_{S}, d_{T}\right)$ は 2 つの距離の組 $\left(d_{S}, d_{T}\right)$ に対して, それらの関係が適切かどうか を反映するスコアを与える。この関数を設定するためにまず実際のデータにおける現象を観 測した。正解のアラインメントが付与された 4 万文の新聞記事対訳コーパス (Uchimoto, Zhang, Sudo, Murata, Sekine, and Isahara 2004) を用いて，距離の組の出現頻度を係数した．図５に観 測結果を示す (状況がとらえやすいように, 別角度からの図を 2 つ示す). 縦軸が頻度の対数で あり，2つの横軸は 2 つの距離にそれぞれ対応する。結果を見ると，距離が等しいペアの頻度 は高く，逆に距離に差があるペアの頻度が著しく低下することがわかる。

この観測結果を踏まえて, 距離一スコア関数 $f\left(d_{S}, d_{T}\right)$ を人手で設定した。このとき, 以下の 条件を満たすようにする：

- $d_{S}$ と $d_{T}$ が共に小さい場合は, 注目した対応候補の関係が適切であると判断できるので, プラスのスコアを与える

- $d_{S}$ と $d_{T}$ が共に大きい場合（距離 10 以上）は，対応候補は互いに関係性を持たないと判 断し，０とする。 

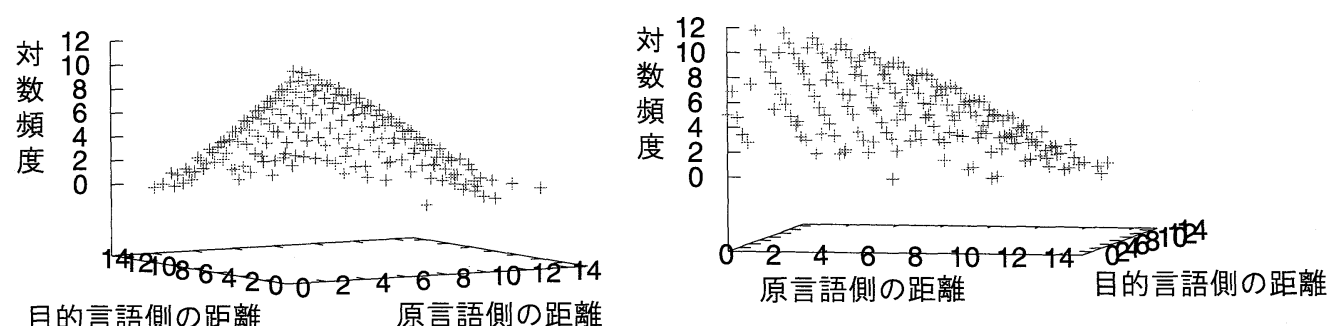

図 5 観測された距離の組の頻度分布

- $d_{S}$ と $d_{T}$ の差が大きい場合は, 対応候補の関係が不適切であると判断できるので，マイ ナスのスコアを与える。

例えば図 4 において, ペア $1\left(d_{S}, d_{T}\right)=(1,1)$ にはプラスのスコアを与えるが, ペア $2\left(d_{S}, d_{T}\right)=$ $(1,7)$ に対してはマイナスのスコアを与える.

\section{5 最適なアラインメントの探索}

アラインメントの整合性は式 1 に示したように, 全ての対応候補ペアの $f\left(d_{S}, d_{T}\right)$ の和として 定義される。また最適なアラインメントは，この和を最大とするアラインメントである．しか しながら，考えうる全てのアラインメントのパターンをチェックしようとすると，組み合わせ 爆発を起こすので, 最適なアラインメントの探索は近似的に行う.

まず，ある 1 つの対応候補 $a_{i}$ に対するスコアを以下のように定義する：

$$
\operatorname{score}\left(a_{i}\right)=\sum_{j \neq i} \text { 整合性スコア }\left(a_{i}, a_{j}\right)
$$

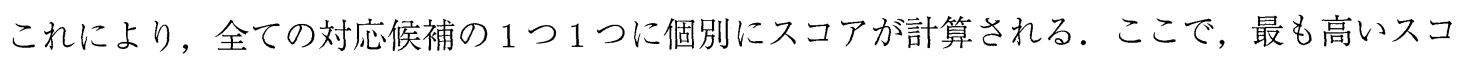
アとなった対応候補は正しい対応であると判断し, 採用する。同時に, 採用された対応と衝突 している対応候補は棄却する。そして各対応候補のスコアを再計算し, 採用・棄却を繰り返す。 これをすべての対応候補が採用か棄却されるまで繰り返すことにより，近似的に最適なアライ ンメントが得られる.

\section{4 実験と考察}

\section{1 アラインメント実験}

正解のアラインメントが付与されている新聞記事の対訳コーパス (Uchimoto et al. 2004) から ランダムに 500 文を選び，これを用いて日英対訳文のアラインメント実験を行なった.アライ ンメントの評価単位は, 日本語は文字単位, 英語は単語単位とした。 日本語の評価単位を単語 
単位としなかった理由は 2 つる。1つは我々の出力と正解データとで形態素解析のずれがあ る場合があることである。もう 1 つは，我々の出力も正解データもアラインメントの単位は句 なのたが，そもそも何を句とするかの定義が定まっていないため，句の区切りにずれがあるこ とである。これらの理由から，評価を単純に，わかりやすくするために，日本語では文字単位 で評価した．なお我々の予備実験により，評価単位を文字単位としても大きな副作用はないこ とが示されている。

対訳辞書として，研究社の和英辞書（見出し語数 $36 \mathrm{~K}$ ，抽出した対訳数 $214 \mathrm{~K}$ ） と，同英和 辞書（見出し語数 $50 \mathrm{~K}$ ，抽出した対訳数 $303 \mathrm{~K}$ ）を用いた.

評価は適合率，再現率，F值により算出し，さらに AER (Och and Ney 2000) も求めた。な お，正解データには $\operatorname{Sure}(S)$ アラインメントのみが付与されており, Possible $(P)$ アラインメン トはない (Och and Ney 2003) $)^{1}$.

実験結果を表 1 に示す。“baseline” はすべての枝の距離を 1 とし，さらに整合性スコア $f=$ $1 / d_{S}+1 / d_{T}$ として実験したものである。“uniform dist.”は枝の距離はすべて 1 だが，整合性ス コアを 3.4 章で定義した関数により計算した場合の結果である。“proposed”は “uniform dist.” の枝の距離を係り受け距離に変更した結果である.

比較実験として，統計翻訳のフリーツールであり，その精度に定評のある“Moses” (Koehn， Hoang, Birch, Callison-Burch, Federico, Bertoldi, Cowan, Shen, Moran, Zens, Dyer, Bojar, Constantin, and Herbst 2007) を利用したアラインメント実験も行なった。トレーニングデータとし て, 毎日新聞 4 万対訳文と読売新聞 25 万文を利用し，日本語文については形態素解析器 JUMAN で形態素に分割した。また 2.2 章で述べた部分文字列アラインメントのみでのアラインメント 精度を “sub-string”に示した。ここでのトレーニングデータは, Moses と同じものを用いた（た だし，日本語の形態素分割は行っていない).

“manual”は，我々の出力を人手により修正したものであり，アラインメントの上限值と見る ことができる。上限値が 100 にならないのは，我々の出力と正解データとのアラインメントの

表 1 アラインメント実験結果

\begin{tabular}{l|rrrr}
\hline & 適合率 & 再現率 & F 值 & AER \\
\hline baseline & 77.47 & 64.32 & 70.29 & 29.71 \\
uniform dist. & 80.30 & 66.90 & 72.99 & 27.01 \\
proposed & $\mathbf{8 0 . 7 7}$ & $\mathbf{6 9 . 1 4}$ & $\mathbf{7 4 . 5 1}$ & $\mathbf{2 5 . 4 9}$ \\
\hline Moses & 60.19 & 33.15 & 42.75 & 57.25 \\
sub-string & 71.48 & 27.81 & 40.04 & 59.96 \\
\hline manual & 95.58 & 89.80 & 92.60 & 7.40 \\
\hline
\end{tabular}

\footnotetext{
${ }^{1}$ Possible $(P)$ アラインメントがない場合, AER = 1- F- measure として計算される.
} 
単位にズレがあることや，正解デー夕自体に誤りが含まれていることがあるためである.

\section{2 考察}

表 1 より，距離スコア関数を改善することにより $\mathrm{F}$ 值で 2.7 ポイントの精度向上が見られる. 実際の言語現象を観測し，それを反映する関数の定義を用いることの妥当性と，その効果の高 さがこの結果から示された。

係り受けスコアを用いることにより，さらに約 1.5 ポイント精度向上したが，距離スコア改善 による向上に比べると差が小さく，係り受けスコアを用いることの利点はそれほどないように 見える. 現在は係り受け距離は人手により設定されているが，この設定が実際の言語の特徴を 十分に反映しているかどうかという点で疑問が残る。今後係り受け距離を自動学習などにより 適切に設定することにより，係り受け距離を利用する効果がより顕著に表れるものと思われる.

距離スコア関数の改善と, 係り受けスコアの利用により, baseline より 4.22 ポイントの精度 向上を達成した．図 6 に改善例を示す。例では日本語の“司法”に対して，英語では “judicial” が二度出現しており，曖昧性が発生している。 baselineではこの曖昧性解消に失敗しており,ア ラインメントが不適切だが, proposed では正しく曖昧性解消が行われ, 正しいアラインメント を得ることができた。しかしながら，日本語で“司法”という語が一度しか出てきていないた め，正確には英語の“our judicial system”は未対応とするのが適切である．このような省略は

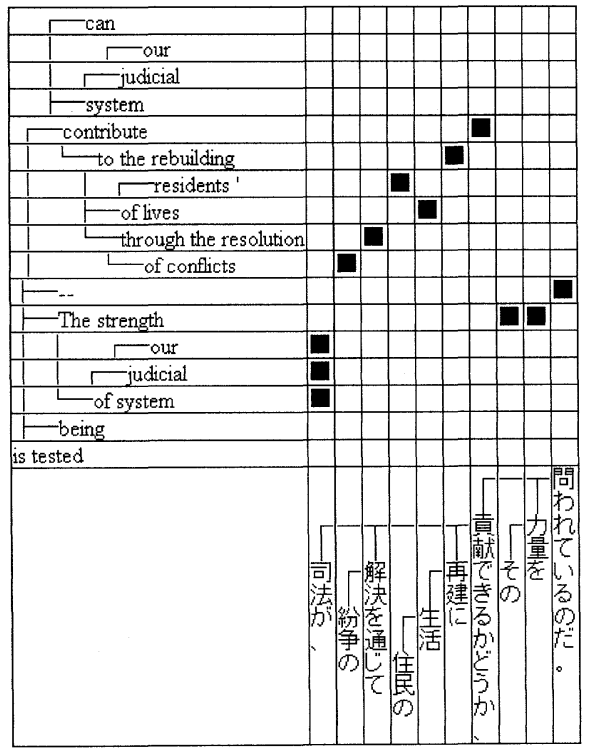

baseline

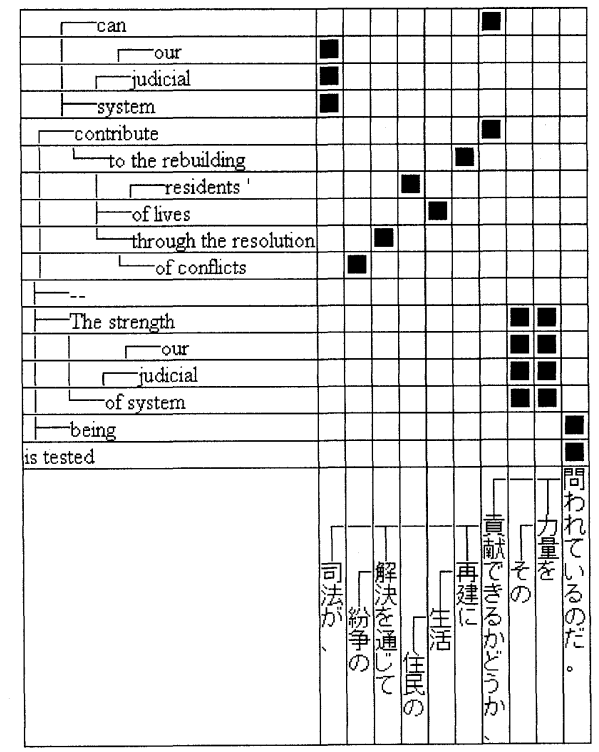

proposed

図 6 アラインメントの改善例 
逆の場合を含め, しばしば起こることであるため, 適切に扱う必要がある。これについては今 後検討する。

我々の提案手法では依存構造を用いており，その情報に強く頼っている部分が大きい。このこ とは今まで述べたとおり非常に有効な手段であるが，一方で依存構造解析の失敗が容易にアラ インメントの失敗につながってしまう。日本語については形態素解析 (JUMAN) の精度が $99 \%$, 構文解析 (KNP) の精度が $90 \%$ あり，高精度ではあるが失敗も $10 \%$ 程度は含まれることにな る．英語ではこれよりさらに精度は低くなり，特に並列構造などでの解析失敗が目立つ。この ため，我々が提案する整合性尺度を利用して，依存構造木自体の修正を可能にする枠組を考案 する必要がある。これにより，アラインメントの精度向上が見込めるだけでなく，基礎技術で ある構文解析技術へのフィードバックを図ることも可能となる.

“Moses”の結果は我々の結果に比べてかなり低い。これは 1 章で述べたように，統計的な手 法が言語構造の異なる言語対に対してはあまり効果が発揮できないことの表れといえる，日本 語と英語では言語構造に大きな違いがあり，例えば日本語ではSOVの語順で文が構成される が，英語ではSVOの語順で文が構成される。このような言語対に対しては，我々の手法のよう に言語処理リソースを用いた深い文解析が必要であると言える。

“sub-string”の結果は“Moses”の結果とほぼ同じであるが, “sub-string”では形態素解析を行っ ていないという点を考慮すると，十分によい結果であると言える．特に適合率を見ると Moses よりも良い結果であり，このことは我々のアラインメントで利用するときには有効である.

表 2 に，関連研究で示された，日英以外の言語対におけるアラインメント精度を示す. HLTNAACL 2003 (Mihalcea and Pedersen 2003)（英語一フランス語と英語一ロシア語）と ACL 2005 (Martin, Mihalcea, and Pedersen 2005)（英語一ロシア語）はそれぞれアラインメントに関する ワークショップでの結果であり，それぞれのワークショップでの最も良い精度を記録した研究の 值である。(Gildea 2003) は英語と韓国語でのアラインメント精度の向上を目指したものである. また最も基本的な統計的単語アラインメントッールである GIZA++ (Rodríguez, García-Varea, and Gámez 2006) を用いてそれぞれの言語対でアラインメントした結果も示す。すべての值は AER である.

表 2 より, 英語一フランス語対でのアラインメントは最も容易であり, 英語一韓国語で最も難

表 2 他言語対でのアラインメント精度 (AER)

\begin{tabular}{l|ccc}
\hline & 英語一フランス語 & 英語一ロシア語 & 英語一韓国語 \\
\hline HLT-NAACL 2003 & 5.71 & 28.86 & - \\
ACL 2005 & - & 26.55 & - \\
\hline (Gildea 2003) & - & - & 32 \\
\hline GIZA++ & 15.89 & 27.19 & 35 \\
\hline
\end{tabular}


しいといえる。これは言語構造の違いが英仏では小さいが，英韓では大きいことからくると思 われる，韓国語は日本語に近いといわれており，日英と同様，アラインメントが難しい．我々 の日英アラインメントの結果をこれらの他言語対での結果と比較しても, 十分高精度であると 言える.

\section{5 結論と今後の課題}

本論文では構造的句アラインメントの精度向上を目的とし, 係り受け距離と距離一スコア関 数 $f\left(d_{S}, d_{T}\right)$ を用いた新しいアラインメント手法を提案した. また対訳文全体のアラインメント の整合性を全ての対応ペアのスコア $f\left(d_{S}, d_{T}\right)$ の和として定義し, 整合性を定量的に評価する 枠組を提案した。これにより，構造的句アラインメントの精度向上を達成し，基本的な統計的 手法に比べておよそ 30 ポイント高いアラインメント精度を実現した。

実験結果から，言語構造の異なる言語対であっても我々の手法は十分に高精度なアラインメ ントを行うことができ，関連研究での他の言語対での結果と比較しても遜色ない結果をあげた。 今後我々の手法を日英以外の言語対に対しても適用し，その有効性を検証したい.

また係り受け距離と距離一スコア関数は現在は人手により設定されているが，実際の言語の 特徴をよりよく反映するモデルを構築し，さらに他言語において人手により設定するコストを 抑えるために，単言語コーパスからパラメータを自動的に学習する手法を考案する必要がある.

アラインメントの失敗例の多くは構文解析誤りによるものである. 現在の枠組では構文解析 結果を完全に信頼して整合性を測っているが，我々の手法が十分に洗練されたものになれば，整 合性尺度に基づいて構文を修正できるような，構文解析とアラインメントが互いに柔軟に影響 しあい，互いの精度向上を行えるような柔軟な枠組を作ることが今後の課題である.

\section{参考文献}

Brown, P. F., Pietra, S. A. D., Pietra, V. J. D., and Mercer, R. L. (1993). "The Mathematics of Statistical Machine Translation: Parameter Estimation." Association for Computational Linguistics, 19 (2), pp. 263-312.

Charniak, E. and Johnson, M. (2005). "Coarse-to-Fine n-Best Parsing and MaxEnt Discriminative Reranking." In Proceedings of the 43rd Annual Meeting of the Association for Computational Linguistics (ACL'05), pp. 173-180 Ann Arbor, Michigan.

Chiang, D. (2005). "A Hierarchical Phrase-Based Model for Statistical Machine Translation." In Proceedings of the 43rd Annual Meeting of the Association for Computational Linguistics (ACL'05), pp. 263-270 Ann Arbor, Michigan. Association for Computational Linguistics. 
Cromieres, F. (2006). "Sub-Sentential Alignment Using Substring Co-Occurrence Counts." In Proceedings of the 44th Annual Meeting of the Association for Computational Linguistics, pp. $13-18$.

Gildea, D. (2003). "Loosely Tree-based Alignment for Machine Translation." In Proceedings of the 41st Annual Meeting on Association for Computational Linguistics, pp. 80-87.

Koehn, P., Hoang, H., Birch, A., Callison-Burch, C., Federico, M., Bertoldi, N., Cowan, B., Shen, W., Moran, C., Zens, R., Dyer, C., Bojar, O., Constantin, A., and Herbst, E. (2007). "Moses: Open Source Toolkit for Statistical Machine Translation." In Annual Meeting of the Association for Computational Linguistics (ACL), demonstration session.

Koehn, P., Och, F. J., and Marcu, D. (2003). "Statistical Phrase-Based Translation." In Hearst, M. and Ostendorf, M. (Eds.), HLT-NAACL 2003: Main Proceedings, pp. 127-133 Edmonton, Alberta, Canada. Association for Computational Linguistics.

Kurohashi, S. and Nagao, M. (1994). "A Syntactic Analysis Method of Long Japanese Sentences Based on the Detection of Conjunctive Structures." Computational Linguistics, 20 (4), pp. 507-534.

Kurohashi, S., Nakamura, T., Matsumoto, Y., and Nagao, M. (1994). "Improvements of Japanese Morphological Analyzer JUMAN." In Proceedings of The International Workshop on Sharable Natural Language, pp. 22-28.

Martin, J., Mihalcea, R., and Pedersen, T. (2005). "Word Alignment for Languages with Scarce Resources." In Proceedings of the ACL Workshop on Building and Using Parallel Texts, pp. 65-74 Ann Arbor, Michigan. Association for Computational Linguistics.

Matsumoto, Y., Ishimoto, H., and Utsuro, T. (1993). "Structural Matching of Parallel Texts." In Proceedings of the 31st Annual Meeting of the Association of Computational Linguistics, pp. 23-30.

Menezes, A. and Richardson, S. D. (2001). "A Best-first Alignment Algorithm for Automatic Extraction of Transfer Mappings from Bilingual Corpora." In Proceedings of the 39th Annual Meeting of the Association for Computational Linguistics (ACL) Workshop on Data-Driven Machine Translation, pp. 39-46.

Mihalcea, R. and Pedersen, T. (2003). "An Evaluation Exercise for Word Alignment." In Mihalcea, R. and Pedersen, T. (Eds.), HLT-NAACL 2003 Workshop: Building and Using Parallel Texts: Data Driven Machine Translation and Beyond, pp. 1-10 Edmonton, Alberta, Canada. Association for Computational Linguistics.

Och, F. J. and Ney, H. (2000). "A Comparison of Alignment Models for Statistical Machine Translation." In Proceedings of the 18th International Conference on Computational Lin- 
guistics, pp. 1086-1090 Saarbrucken, Germany.

Och, F. J. and Ney, H. (2003). "A Systematic Comparison of Various Statistical Alignment Models." Association for Computational Linguistics, 29 (1), pp. 19-51.

Rodríguez, L., García-Varea, I., and Gámez, J. A. (2006). "Searching for alignments in SMT. A novel approach based on an Estimation of Distribution Algorithm." In Proceedings on the Workshop on Statistical Machine Translation, pp. 47-54 New York City. Association for Computational Linguistics.

Sadler, V. and Vendelmans, R. (1990). "Pilot Implementation of a Bilingual Knowledge Bank." In Papers presented to the 13th International Conference on Computational Linguistics, pp. $449-451$.

Sato, S. and Nagao, M. (1990). "Toward Memory-based Translation." In Papers presented to the 13th International Conference on Computational Linguistics, pp. 247-252.

Uchimoto, K., Zhang, Y., Sudo, K., Murata, M., Sekine, S., and Isahara, H. (2004). "Multilingual Aligned Parallel Treebank Corpus Reflecting Contextual Information and Its Applications." In Proceedings of the MLR2004: PostCOLING Workshop on Multilingual Linguistic Resources, pp. 63-70.

Watanabe, H., Kurohashi, S., and Aramaki, E. (2000). "Finding Structural Correspondences from Bilingual Parsed Corpus for Corpus-based Translation." In Proceedings of the 18th International Conference on Computational Linguistics, pp. 906-912.

南不二男 (1993). 現代日本語文法の輪郭. 大修館書店.

\section{略歴}

中澤 敏明：2005 年東京大学工学部電子情報工学科卒業. 2007 年同大学院修士

課程修了. 2007 年京都大学大学院博士後期課程入学. 機械翻訳の研究に従事.

黒橋 禎夫：1989 年京都大学工学部電気工学第二学科卒業. 1994 年同大学院

博士課程修了. 京都大学工学部助手, 京都大学大学院情報学研究科講師, 東 京大学大学院情報理工学系研究科助教授を経て, 2006 年京都大学大学院情報 学研究科教授, 現在に至る. 自然言語処理, 知識情報処理の研究に従事.

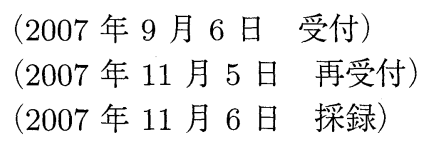

